\title{
Eluloo- ja suulise ajaloo uurimine Leedus
}

\begin{abstract}
Irena Šutinienè
Teesid: Artikli eesmärk on anda ülevaade eluloouurimise ja suulise ajaloo peamistest teemadest ja valdkondadest Leedus alates 1990. aastatest. Ülevaatesse hõlmatatakse uurimistööd, mille analüüsiobjektiks on suulised või kirjalikud autobiograafilised narratiivid või mis käsitlevad ajaloosündmuste isiklikke kogemusi. Samuti tehakse lühikokkuvõte biograafiliste andmete kogumise ja arhiivide loomise institutsioonilistest tegevustest Leedus.
\end{abstract}

Märksõnad: eluloouurimine sotsioloogias, identiteet, regionaalsed uuringud, sotsialismi- ja postsotsialismi uuringud, suuline ajalugu, vähemused

Eluloo- ja suulise ajaloo uurimine Leedus sai alguse pärast taasiseseisvumist ja üldiselt iseloomustab seda Lääne teoreetiliste ja metodoloogiliste võimaluste rakendamine Leedu kogemusele. Tuleb märkida, et just see empiiriline reaalsus või täpsemalt öeldes ajalooline reaalsus stimuleeris olulisel määral mitte ainult isikumälestuste ja elulugude esilekerkimist ja kogumist, vaid mõjutas ka eluloo- ja suulise ajaloo uurimise põhiteemasid. Siiani ei ole eluloouurimise valdkonnas tehtud kuigi palju akadeemilisi uurimusi, kuid mälestuste ja elulugude kogumine ja mittekonventsionaalne kasutamine (ajakirjanduses, regionaaluuringutes jms) on märkimisväärselt laialt levinud. Käesoleva artikli eesmärk on anda ülevaade eluloouurimise ja suulise ajaloo peamistest teemadest ja valdkondadest, samuti põhilistest tulemustest Leedus. Käsitletakse teaduslikke töid, mis vastavad järgmistele kriteeriumitele: esiteks akadeemilised uurimistööd, mis on läbi viidud kooskõlas eluloo- või suulise ajaloo uurimise metodoloogia ja reeglitega; teine kriteerium on seotud peamiselt elulooja suulise ajaloo uurimise olemusliku definitsiooniga, ja sel puhul on rõhk elulool (mõlemas mõttes - nii elu ajalugu kui elu lugu) või isikliku kogemuse jutustamise dimensioonil (Kohli 1986: 93). Seega on eluloouurimise osas käesolevasse ülevaatesse hõlmatud üksnes uurimistööd, mis käsitlevad suulisi või kirjalikke autobiograafilisi narratiive (või narratiivide osi), suulise ajaloo osas hõlmab käesolev ülevaade töid, mis käsitlevad ajaloosündmuste isiklikke ko- 
gemusi. Peamisi valdkondi ja uurimisteemasid esindama valiti kõige ulatuslikumad tööd (dissertatsioonid, monograafiad), samuti uurimistööd, mida võib käsitleda uurimisteemade ja -metoodika mitmekesisust väljendavate iseloomulike näidetena. Artikkel annab ka lühikokkuvõtte biograafiliste andmete kogumise (elulood vastavad enam-vähem eluloo- või suulise ajaloo uurimise metodoloogilistele kriteeriumitele) ja arhiivide loomise institutsioonilistest tegevustest.

\section{Eluloouurimine Leedus: uurimisteemad ja -valdkonnad}

Nagu teisteski riikides, stimuleerisid Leedus eluloo- ja suulise ajaloo uurimist teadlaste hulgas üldiselt tingimused, mis määrasid sotsiaal- ja humanitaarteadustes kvalitatiivse ja biograafilise pöörde: individualiseerumise kasv, sotsiaalse elu subjektiviseerumine, s.o individuaalse sotsiaalse teguri rolli suurenemine võrreldes "struktuuride" rolliga (Alain Touraine, Anthony Giddens jt). See tekitas huvi mikrosotsioloogia ja elulugude tõlgendamise meetodite vastu; eriti eluloouurimist võib mõjutada ka autentsuse romantika, nagu on öelnud David Silverman (2000: 11). Sotsiaalse reaalsuse diakroonilisi, protsessipõhiseid aspekte avavate meetodite populaarsuse tingis nende tähtsus piirkondades, kus elati läbi hulgaliselt suuri ajaloolisi muutusi ja murranguid. Sellistes tingimustes muutub eluloo ja ajaloo põimumine eriti nähtavaks: eluloo biograafiline aeg, struktuurid ja järjestus on kindlalt fikseeritud ajalooliste sündmuste ja muutustega ning ajaloolised kontekstid muutuvad elulooreaalsuseks. Nagu teadlased on märkinud, ei ole elulugu sellistel tingimustel üksnes individuaalse praktika ja sotsiaalse struktuuri kokkupuutepunkt (Bertaux 1981: 6), vaid ka vahend, olgugi tihti traumaatiline vahend, mille abil tulla toime selliseid struktuure lõhkuvate sündmustega (Rosenthal 1993: 21-29). Martin Kohli järgi tuleb [meil] analüüsida biograafilise normaalsuse struktuuri ja lühiajaliste ajalootõusude ja -mõõnade omavahelist suhet. Küsimus on selles, kuidas püüavad indiviidid saavutada normaalset biograafiat antud ajaloolistes tingimustes; s.t kuidas nad saavad hakkama institutsionaliseeritud järjestikuste elumustritega konkreetses ainulaadsete ajaloosündmuste jadas (Kohli 1986: 95). Nii järeldab M. Kohli eluloouurimise kohta Saksamaal, et iga eluloouurimine [---], isegi selline, mis ei ole põhiosas otseselt seotud suulise ajalooga, peab samal ajal olema ajaloouurimine (Kohli 1986: 94). See väide kehtib samal määral ka Ida-ja KeskEuroopa riikide puhul. 
Eluloouurimise teemad ja valdkonnad Leedus kinnitavad, et elulugude analüüsimisel on raske vältida ajaloolist dimensiooni, mis väljendab üksikisiku suhet ajaloo teguritesse ja muutustesse; ajaloosündmused, -epohhid, -protsessid peegelduvad ühel või teisel viisil isegi juhul, kui uuritakse selliseid konkreetseid nähtusi nagu armastus, abielu jms. Üksikisiku ja kollektiivi vajadus tulla toime ühiskondlik-poliitiliste murrangute ja muutuva poliitilise režiimiga on määrav suures osas nii isiklike mälestustekstide loomise ja kogumise kui ka eluloo- ja suulise ajaloo uurimise puhul. Eluloouurimise üks erijoon, mida näivad mõjutavat ajaloo transformatsioonid, on sotsiaalse identiteedi ja tervikliku eneseidentiteedi konstrueerimise tähtsus. See tuleb esile enamikus uurimustes, isegi sellistes, mis põhiosas keskenduvad teistele teemadele. Kuigi biograafiline mõtlemine (biographical work) on seotud enesemääratlemisega, muutub üksikisiku ja tema subjektiivsuse (eluloo jutustamine on osa sellest) roll üha tähtsamaks situatsioonides, kus toimuvad ühiskonna tõsised struktuursed ümberkorraldused; terviklik eneseidentiteet (või biograafilise mõtlemise kaudu loodud enesemüüdi terviklikkus) muutub väga oluliseks vahendiks, struktureerimaks hävitatud maailma ja leidmaks enda praktilist suundumust. Wolfram Fischer-Rosenthal väidab, et üksikisikud, kes elavad muutuva ühiskonna keerises, elades üle igasuguseid kaotusi, tegelevad biograafilise mõtlemisega tegelikult selleks, et leida praktiline suundumus ja jääda ellu (Fischer-Rosenthal 1995: 260). Akadeemilises eluloouurimises käsitletakse eluloolist jutustamist tihti eneseidentiteedi loomisena: Elulookirjelduse koostamise käigus võib inimene avastada, kelleks ta on saanud (Fischer-Rosenthal 1995: 261), kuigi need sotsiaalsed protsessid ei sõltu terminoloogiast, mida sotsioloogid soovitavad neid uurides kasutada (Fischer-Rosenthal 1995: 260).

Leedu uurimistöödes on kasutatud kõiki kolme meetodit, mida Robert Miller on määratlenud realistliku, neopositivistliku ja narratiivse meetodina (Miller 2000: 113-159). Ülekaalukaim on esimese, realistliku meetodi kasutamine. Paljudel juhtudel nimetatud kolm meetodit kattuvad ja täiendavad üksteist. See on loomulik, sest praktikas kalduvad eluloouurimused olema eklektilised ja iga lähenemisviisi võtteid kasutatakse pragmaatiliselt, lähtudes otstarbekuse põhimõttest (Miller 2000: 156); nii on see ka Leedus, kus metodoloogiline eklektika aitas päris edukalt näidata sotsiaalse reaalsuse mõningaid aspekte.

Metodoloogia probleeme ei ole Leedu teadlased laiemalt arutanud. Arutelu all on sotsiaalajaloolise ja biograafilise aja küsimused selliste mõistete nagu kohort ${ }^{1}$, biograafia, põlvkond käsitlemisel; identiteedi ja autobiograafia suhted (Kraniauskienè 2002a; Kraniauskienè 2007); biograafilise ja teiste meetodite kooskõla ning teised küsimused. Esile on kerkimas ka ajaloolaste metodoloogiline arutelu suulise ajaloo rollist erinevate teemade ajaloolisel käsitle- 
misel (repressioonid, vastupanuliikumine, kohalikud kogukonnad jne) (Potašenko 2006b; Marcinkevičienè ilmumas).

Esimesed empiirilised eluloouurimused tegi Laima Žilinskienė Vilniuse Ülikoolist konkreetsete elavike erinevatest aspektidest ja etnilistest rühmadest. 1994. aasta eluloouurimuses analüüsis ta vene ja poola rahvusvähemuste, aga ka leedulaste hoiakuid ja arvamusi. L. Žilinskienè teine uurimistöö 1998. aastast seadis eesmärgiks Vilniuses ja selle lähiümbruses elavate leedulaste ja poolakate elude kirjeldamise (sellesse piirkonda on koondunud poola rahvusvähemus) (Žilinskienė 1998). Samal ajal korraldati Vilniuse Ülikoolis kaks elulookirjutamise võistlust. Neist esimene, "Minu elu lugu" korraldati 1995. aastal. Selle võistlusega koguti üle 200 elulookirjelduse (autorite vanus 13-89). ${ }^{2}$ Teise, 1997. aasta kogumisvõistluse "Minu seksuaalelu lugu" käigus koguti üle 100 eluloo, selle korraldas Laima Žilinskienè koostöös Helsingi Ülikooliga.

Natalija Kasatkina (Leedu Sotsiaaluuringute Instituut), sotsioloogia ja suulise ajaloo seisukohast käsitlenud vene diasporaad Leedus aastail 1918-1940. Väitekirjas Vene haritlaskonna integreerumine Leedu kultuuriga sõdadevahelisel perioodil (Kasatkina 1994) on ta kasutanud kvalitatiivset ja kvantitatiivset analüüsi: vene diasporaa ajalehtede ja perioodiliste väljaannete sisuanalüüs ning rahvaloenduse andmete analüüs on ühendatud isiklike dokumentide (kirjade, päevikute jms), avaldatud memuaaride ja biograafilistest intervjuudest pärinevate andmete kvalitatiivse analüüsiga. Autor on kogunud 75 suulist autobiograafiat ja kirjalikke mälestusi. Uurimus toob esile Teise maailmasõja eelses Leedu Vabariigis elanud vene haritlaste kultuurilise integratsiooni põhijooned, arusaamad ja identiteedi.

Sotsioloog Sigita Kraniauskienè (Klaipėda Ülikool) väitekiri (Kraniauskienė 2003) ja artiklid käsitlevad soolise sotsialiseerumise protsessi ja struktuuri dimensioone, aga ka soolise ja põlvkonnaidentiteedi loomist 20. sajandi Leedu ühiskonnas. Kõik uuritud aspektid on seotud ajalooliste transformatsioonide ja üksikisiku biograafilise mõtlemise omavaheliste seostega. S. Kraniauskienè uurimus põhineb ülalmainitud võistlusele "Minu elu lugu" saadetud elulugude korpuse analüüsil. Neis elulugudes esitatud narratiivid, meenutused ja ajaloopildid hõlmavad pikka perioodi - 19. sajandi viimastest kümnenditest 20. sajandi lõpuni. Soolise sotsialiseerumise ja soolise identiteedi loomise protsessi iseloomustab individualiseerumine, identiteediloome subjektiivsus ja eneseidentiteedi peegeldamine, mida S. Kraniauskienė mõistab kui nihet traditsiooniliselt kaasaegsele nii eneseidentiteedi kui autobiograafilise narratiivi ülesehituses (Kraniauskienè 2002b: 66-74). Eluloouurimine võimaldas läheneda soolisele identiteedile kui üksikisiku ja ühiskonna sotsiaalsete normide kogumile ning uurida soolise väljenduse printsiipe ühiskonnas. Analüüs näitas, missugused sooliste suhete mehhanismid juhivad üksikisiku sotsiaalseid tavasid 
ja sooidentiteedi sotsiaalset konstrueerimist (Kraniauskienė 2005). Sama elulookogu põhjal jälgis S. Kraniauskienè põlvkonnaidentiteeti (Kraniauskienè 2004a), käsitledes elulugusid ajalooliste ja biograafiliste protsesside kokkupuutepunktidena. Uurides sotsiaalse identiteedi loomist nagu see ilmneb autobiograafiates, eristab ta 20. sajandi Leedu ühiskonnas kolme kohorti: aastatel 1910-1922, 1923-1944 ja 1945-1957 sündinud. Põlvkonnakohortide kindlaksmääramise järel uuris ta nimetatud põlvkondade sümboolseid piire, et näha, kuidas iseseisvusideele omistati erinevaid sotsiaalseid tähendusi ja kuidas see idee töötas peamise põlvkondade eristajana (Kraniauskienè 2004b). Põlvkondlikest erinevustest hoolimata püüdsid inimesed kõigis 1995. aastal kirjutatud elulugudes leida sümboolseid või reaalseid seoseid sõjaeelse Leedu Vabariigiga, põhjendamaks oma õigust kuuluda uude iseseisvasse Leedusse. Esimese põlvkonna (snd 1910-1922) elulugudes on tendents siduda see idee orgaanilise kontekstina elulugudesse. Teise põlvkonna (1923-1944) hinnang minevikusuhtele oli jäik ning nende kirjutamisaegne identiteet otseselt seotud minevikus tehtud otsuste ja valikutega. Kolmas põlvkond (1945-1957) pidas iseseisvust millekski, mis eraldas neid eelmistest põlvkondadest.

Leedu Sotsiaaluuringute Instituudi uurija, sotsioloog Aušra Maslauskaitè käsitles armastuse sotsiaalse konstruktsiooni teemasid muutuvas Leedu ühiskonnas (Maslauskaite 2003, 2004). Ta on leidlikult kasutanud eluloouurimise meetodite eeliseid, mis toovad esile subjektiivsete protsesside dünaamika ja seosed sotsiaalsete kontekstidega (antud juhul sotsiaal-struktuurilised ja kultuurilised transformatsioonid), uurides Leedu sotsioloogias varem uurimata armastuse teemat. Selles töös on eluloouurimine ühendatud diskursuse-analüüsiga. Autor jälgis, kuidas sotsiaalse ja individuaalse koosmõjul tekivad ja muutuvad hoiakud, vä̈̈rtusorientatsioonid ja moraalsed otsustused (Maslauskaite 2004: 202). Uurija teine eesmärk oli avastada sotsiaalstruktuursete ja kultuuriliste transformatsioonide ning üksikisiku tasandil sotsiaalsete teadmiste muutumise omavahelisi seoseid. Ta analüüsis 40 tüüpilise noore abielupaari elulugu. Uurimistöö näitas, kuidas on sotsiaalsed teadmised inimestevahelistest suhetest seotud eneseidentiteediga. Autori sõnul on inimese minakontseptsioon tugevas korrelatsioonis armastuse kontseptsiooniga või armastussuhte mõistmisega ja nende loomise viiside valikuga (Maslauskaite 2004: 213). Samuti eristab ta kahte eneseidentiteedi tüüpi - individualistlik ja traditsiooniline - mis sarnanevad S. Kraniauskienè ülalmainitud töös esitatutega. Muuhulgas püstitab A. Maslauskaite ka küsimuse sotsiaalsete determinantide (sotsiaalne taust, päritolupere eluviis) mõjust indiviidi eneseidentiteedile ja sotsiaalsele mobiilsusele. Autor leiab, et kiirete sotsiaalpoliitiliste muutuste ajal mõjutab edukust mitte päritoluperekonna sotsiaalne staatus, vaid selle kultuuriline kapital. 
Suulise ajaloo populaarset valdkonda - nõukogude perioodi traumaatiliste sündmuste ja nende tagajärgede ajalugu - on Leedus analüüsitud ka kultuuriuuringute aspektist. Violeta Davoliūtè (Toronto Ülikool) uurimus deporteeritutest Leedu ajaloos (Davoliūtè 2005) käsitleb ajalootraumade mõju individuaalsele ja kollektiivsele identiteedile. Autor analüüsib Leedust Siberisse küüditatud Dalia Grinkevičiūtè autobiograafiliste mälestuste kahte versiooni, mis on kirjutatud 1949. ja 1976. aastal. Need mälestused on tõenäoliselt parimad teadaolevad tunnistused leedulaste massiküüditamistest nõukogude perioodil. 1980. aastate lõpul sai neist memuaaridest rahva kollektiivsete kannatuste sümboolne väljendus, mis oli väga oluline elanikkonna mobiliseerimiseks taasiseseisvumise aastatel. Mälestuste kihid peegeldavad traumaatilistele kogemustele erinevatel eluetappidel omistatud tähendusi ning see võimaldab seostada meenutustest leitavaid tunnuseid elukogemuses kui protsessis eristuvate tunnustega. V. Davoliūtė näitab, et protsess, mille käigus memuaaride autorist saab eetiliselt küps indiviid, on tihedalt seotud territoriaalse ja sugulusel põhineva kuuluvuse ümberhindamisega. Dalia Grinkevičiūtė mälestustes on alati esikohal eetilised põhimõtted ning tema samastumine režiimi moraalse hindamise eetilise kogukonnaga, mitte enesevalitsuse kaotanud küüditatute ja dissidentidega, nagu ka tema tunnistus kõigi režiimi ohvrite nimel, ületab rahvuse piirid. Kuid see eetiline kogukond ei ole väljaspool konkreetseid inimesi, sündmusi ja rahvusi, vaid nende sees: Grinkevičiūtė tunnistus esindab eetilist kogukonda, mis täiendab, kuid ei asenda sugulusstruktuure, mis kerkivad esile kõigis kogukondades (Davoliūtè 2005: 63). Siberi üleelanud leedulaste autobiograafilisi memuaare analüüsis 2000. aastal võrdleva kirjandusteaduse teadur Jura Avižienis (Lõuna-Maine’i Ülikool), kelle väitekiri Ajaloo tunnistaja (2006) ja teised publikatsioonid (Avižienis 2005, 2006) käsitlevad elulugude, mälu ja ajaloo probleemistikku.

Ajaloolase Dalia Marcinkevičienè (Vilniuse Ülikooli Soouuringute keskus) uurimus ühendab suulise ajaloo ja soouuringud. Ta analüüsis ja avaldas tüüpilisi naiste elulugusid sõjajärgsest Leedust, Hruštšovi ajast ja Brežnevi valitsemisaja algusest. D. Marcinkevičienè koostatud teos (Marcinkevičienė 2007) sisaldab 10 elulugu ja nende analüüsi. Elulugude avaldamise eesmärk on näidata erinevatest sotsiaalsetest gruppidest, erineva sotsiaalse staatuse ja haridusega naiste kogemust, aga samuti esitada vaatlusaluse perioodi (1945-1970) argielukontekste. Autor keskendub naiste identiteedi arengule nõukogude perioodil. Uurimuslikus osas on erilise tähelepanu all nõukogude ideoloogia mõju naisele kui subjektile (sotsiaalsetele teadmistele ja arusaamadele rollidest ja muust, mis mõjutab identiteedi loomist); samuti vaadeldakse naiste identiteedi ümberhindamise küsimusi ajalooliste ümberkorralduste perioodil pärast kommunismi kokkuvarisemist. Analüüsides naisidentiteedi arengut okupeeritud 
Leedus rõhutab D. Marcinkevičienė nõukogude ideoloogia mõju sellele protsessile. Autori arvates avaldub kõnesolev mõju selles, et enamasti on naiste lugudes nõukogude aega puudutavad mälestused katkendlikud, ebaloogilised ja sõnastatud nõukogude propagandat meenutavalt:

Naised kirjeldasid arusaadavalt ja üksikasjalikult oma elu kuni nõukogude okupatsioonini 1940, mäletasid elavalt Teist maailmasõda ja sõjajärgseid aastaid. Viiekümnendate aastate keskpaik oli punkt, mil eluloointervjuud naistega muutuvad katkendlikuks, need piirduvad vaid nappide elulooliste pisiseikadega, intervjuude keelekasutus meenutab propagandistlikke ajaleheklišeid (Marcinkevičienè 2007: 19).

Selles uurimuses pärinesid kõige terviklikumad ja selgemad eluloojutustused naistelt, kes olid kas nõukogude režimi heidikud või ühiskonnas kõrgel sotsiaalsel positsioonil ja seega suurel määral režiimile lojaalsed. Autor märgib, et lood erinevad üksteisest sellest sõltuvalt, millist hinnangut püüdsid naised nõukogude perioodile anda ja see omakorda on seotud nende naiste tolleaegse identiteediga. Autor järeldab leedulannade teadmiste, tegude ja emotsioonide vahelisest lõhest tol perioodil, et kuigi enamik Leedu naisi võtsid omaks rolli, mille nõukogude propaganda neile peale sundis, jäid nad emotsionaalselt pigem ühiskonnaelu vaatlejateks kui aktiivseteks osalejateks (Marcinkevičienè 2007: 32).

Antropoloog Aušra Simoniukštytè (Vilniuse Ülikool) eluloouurimus põhineb suulise ajaloo ja antropoloogia metodoloogial ning keskendub Leedu mustlaste ajaloole ja kultuurile, tuues esile nende eluilma eripära (Simoniukštytė 2003). Uurimus kirjeldab territoriaalsuse, kodumaa ja sünnikoha tähendust Leedu mustlaste silmis, aga ka nende elulaadi, samas näidates Leedu elanikkonna seas mustlaste kohta levinud stereotüüpide ja eelarvamuste ekslikkust. Muude teemade hulgas käsitleb autor ka kollektiivset mälu mustlaste holokaustist Teise maailmasõja ajal ning teistest traumaatilistest sündmustest, kultuurisuhteid mustlaste ja leedulaste vahel, nõukogude ajal ja osaliselt Saksa okupatsiooni aastatel pealesurutud paikse eluviisi tagajärgi.

Minu uurimus sotsiaalsest mälust nõukogude perioodil, eriti aastate 19401953 traumaatiliste ajaloosündmuste mäletamisest, vaatleb suulist ajalugu sotsioloogia meetoditega (Šutinienè 2003). Uurimus põhineb 1939. aastal sündinute ja vanematega tehtud eluloointervjuudel ja jälgib kahte omavahel seotud teemat: autobiograafilise ja kollektiivse mälu konstrueerimise strateegiaid nõukogude ajal (erilise tähelepanuga traumaatiliste sündmuste mäletamisele) ning seoseid nõukogude perioodi mäletamise strateegiate ja selle perioodi elukogemuse vahel. Uurimus näitas, et nõukogudeaegsete traumaatiliste sündmuste mäletamise strateegiad, nagu need avalduvad autobiograafilistes narratiivi- 
des, on suurel määral seotud kollektiivse mälu sotsiaalsete funktsioonidega. Teatud lood püüavad näidata individuaalset ja kollektiivset minevikukogemust normaalsena praeguste moraalsete ja poliitiliste väärtuste ja identiteetide valguses. Koostöö nõukogude režiimiga ja selle tunnustamine on pigem seotud traumaatilise nõukogude mineviku "amneesiaga" ja püüuga näidata seda suhtelisena, samas iseloomustab võimude poolt represseeritute ja ka üsna depolitiseeritud elu elanud inimeste jutustusi tõepüüdlus. Nõukogudeaegse mineviku mäletamise valikulisus on seotud sellega, kui edukad ollakse integreeritud eneseidentiteedi (tervikliku enesemüüdi) biograafilisel loomisel. Narratiivi järjepidevuse puudumine, selle nõrkus või võimetus rääkida teatud eluperioodidest tulenevad erinevatest põhjustest: ajalooline amneesia; nõukogude aega õigustava avaliku diskursuse puudumine; igapäevaste toimetuste kirjeldamatus; teatud sündmuste ja perioodide tähtsusetus (vähene mõju inimese elule); esineb ka suutmatust väljendada traumaatilist kogemust, kuigi enamasti on sellise kogemusega inimestel vajadus sellest jutustada. Minu teine elulooalane uurimus (Šutinienè 2008) põhineb Leedu küüditatute ja Gulagi vangide autobiograafiliste jutustuste analüüsil. Selle eesmärk on tuua esile küüditamiste ja Gulagi kogemuste mäletamise biograafilised tähendused. Analüüsisin traumaatilisest mälestusest rääkimisel esinevaid raskusi mälestuse aja-, koha- ja moraalsete raamide määratlemisel, küüditamis- ja vangilaagrimälestuste sõltuvust pärast vabanemist kogetud jätkuvast tagakiusamisest, küüditamismälestuste ja traumaatilise kogemusega toimetulemise omavahelisi suhteid ning kollektiivsetele kannatustele keskenduva avaliku narratiivi mõju individuaalse mälu väljendustele.

Minu uurimus holokausti mäletamisest (Šutinienè 2004) kuulub põhiosas suulise ajaloo ja mälu-uuringute valdkonda ning selle eesmärk on uurida väikelinnade elanike tänaseid mälestusi holokaustist, samuti rekonstrueerida inimeste arusaamu ja suhtumist juutidesse ja holokausti Teise maailmasõja ajal. Uurimus põhineb Leedu erinevates osades tehtud intervjuudel. Analüüsin veel vastavaid stereotüüpe, raskusi holokausti meenutamisel pärast nõukogudeaegset pealesunnitud amneesiat, erinevusi inimeste selleteemaliste mälestuste ja avaliku diskursuse vahel.

Töös olevatest projektidest mainigem Leedu emigrantide rahvusidentiteedi muutuste uurimist (Vytis Čiubrinskas, Jolanta Kuznecovienè jt, Vytautas Magnuse Ülikool), ajude äravoolu protsesside uurimist (Ingrida Gečienè, Sotsiaalsete Innovatsioonide Instituut) jne.

Suurim hulk suulise ajaloo valdkonna uurimistöid tehakse arvatavasti regionaalteemadel. Neid uurimusi koostavad nii eri distsipliinide teadlased kui ka amatööridest koduloouurijad. Tähelepanuväärseim projekt on koguteoste sari "Lietuvos valsčiai" (Leedu vallad), mille on koostanud ja avaldanud kirjas- 
tus Versmè. ${ }^{3}$ Alates 1994. aastast on avaldatud 18 suuremahulist (umbes 800 1200 lehekülge) koguteost riigi erinevate valdade kohta. Kirjastuse eesmärk on välja anda koguteosed riigi kõigi piirkondade kohta. Sarja iga osa autorite arv on suur - 40-80 inimest, enamik neist erinevate alade teadlased - ajaloolased, etnoloogid, arheoloogid, sotsioloogid, keeleteadlased, folkloristid, geograafid jne, kuid raamatud sisaldavad ka asjaarmastajatest koduloolaste uurimusi. Suulise ajaloo uurimused hõlmavad neis laia teemaderingi: staliniaegsete repressioonide ajalugu ja mõjud, partisanide vastupanuvõitlus, sõda, holokaust, kollektiviseerimine ja teised nõukogude perioodi traumaatilised sündmused, institutsioonide ajalugu, etniliste ja religioossete gruppide ajalugu ja kultuur jne. Mõnes kirjutises on suulise ajaloo tekste kasutatud mitte kesksete, vaid lisaallikatena dokumentaalsete ja teiste ajalooliste allikate kõrval, rekonstrueerimaks ajaloolisi sündmusi, fakte jne.

Suulise ajaloo metoodikat ja akadeemiliste institutsioonide uurimistööde andmeid kasutatakse ka ajalooalastes töödes, milles neid kombineeritakse teiste metoodikate ja ajalooallikatega. Neid kasutatakse enamasti seoses 20. sajandi, eriti nõukogude perioodi ajalooga. Head näited suulise ajaloo akadeemilistest rakendustest kultuuri-, sotsiaal- ja regionaalajaloolistes uurimustes on Grigori Potašenko (Vilniuse Ülikool) töö Leedu vanausuliste kogukonnast 20. sajandil (Potašenko 2006a) ja Rasa Račiūnaitè (Kaunase Vytautas Magnuse Ülikool) uurimus Kaunase linnaosade ajaloost (Račiūnaitė 2004).

\section{Elulugude ja suulise ajaloo tunnistuste kogumine}

Autobiograafiliste mälestuste ulatuslikum kirjutamine, kogumine ja avaldamine tekkis Leedus, nagu ka teistes postsotsialistlikes riikides taasiseseisvumise ajal või mõnevõrra varem, glasnosti ajal, kui tekkis võimalus avalikustada varem allasurutud kollektiivset ja personaalset mälu. Enamasti oli tegemist stalinlikke repressioone kogenud inimeste mälestustega, kuid hakkasid levima ka nõukogude perioodi teiste, ajaloolise traumana tunnetatud dramaatiliste sündmuste tunnistajate memuaarid. Selle põhjustas nende sündmuste ajalooline tähtsus ja massiline traumaatiline mõju, sest need tähtsad ja laialdaselt kogetud ajaloosündmused või etapid, mis on äärmuslikult ja valusalt mõjutanud teatud regiooni või riigi elanike argielu, kutsuvad esile jutustamise (Rosenthal 1991: 34). Need meenutused olid olulised ka Leedu rahvusluse seisukohalt ja tugevdasid müüte kollektiivsest kannatusest, mis olid sel ajal tähtsad rahvusliku mobiliseerimise ja rahvusidentiteedi (re)konstrueerimiseks. Mõned neist, teiste hulgas juba mainitud endise küüditatu Dalia Grinkevičiūtè lugu, muutusid sümboolseteks küüditamislugudeks ja hakkasid käsitsi pal- 
jundatuna levima alates 1987. aastast. Endiste küüditatute ja Gulagi vangide lood olid tihedalt seotud inimeste isiklike mälestustega sõjajärgsest partisanivõitlusest, nõukogude ja Saksa okupatsioonist ning nõukogudeaegsest dissidentide liikumisest. See spontaanne traumaatilist kogemust käsitlevate isikulugude laine tõi kaasa paljude memuaaride avaldamise, neid kirjutatakse ja avaldatakse siiani, kuigi tiraažid on nüüd väiksemad.

Mälestuste ja elulugude sihipärane kogumine algas 1988. aastal. Algul korraldasid seda ühiskondlikud organisatsioonid, kuid see kogumislaine piirdus vaid ülalmainitud konkreetsete teemadega ega muutunud elulooliikumiseks, nagu 20. sajandi teisel poolel Poolas, kus elulugude kirjutamine ja elulookirjutamise võistlused olid ja on tänini väga populaarsed. Hiljem muutus see tegevus Leedus institutsioonikesksemaks. Mainin vaid põhilisi asutusi, et anda aimu tegevuse ulatusest.

Suulisi ja kirjalikke mälestusi koguvad mitmed ühiskondlikud organisatsioonid: (endiste) küüditatute ja Gulagi vangide, erinevad sõjaveteranide ning holokausti üleelanute ühendused, samuti paljud koduloouurimise seltsid jms. Sama laadi jutustusi koguvad ka muuseumid. Mõned neist organiseerivad ka kogutud mälestuste avaldamist.

Tähtsaim nõukogude perioodi suulise ajaloo andmete kogumise ja uurimise asutus on Leedu genotsiidi ja vastupanuliikumise uurimiskeskus (Lietuvos gyventoju genocido ir rezistencijos tyrimo centre, vt keskuse kohta pikemalt http://www.genocid.lt/centras/en/). Kogutakse sündmuste tunnistajate ja neis osalenute suulisi mälestusi, mida kasutatakse ajaloouurimise allikatena. Keskus kogub ja töötleb ka ühiskondlike organisatsioonide kogutud mälestusi. Suulise ajaloo tunnistusi kogutakse kahe programmi raames: "Elav mälu" ja "Küüditamise ja vangistuse kohad". Programmis "Elav mälu" salvestatakse mälestused heli- ja videokandjatele, materjali töödeldakse ja liidetakse andmebaasi, mida saab hiljem kasutada teaduslikel ja hariduslikel eesmärkidel, näituste, filmide ja CDde ettevalmistamisel. Praeguseks on helis ja pildis salvestatud 250 lugu, jutustajateks endised vastupanuvõitlejad, sh 1941 juuniülestõusus osalenud, Teise maailmasõja erinevad osapooled, küüditatud ja Gulagi vangid jt. Programmi "Küüditamise ja vangistuse kohad" eesmärk on koguda ja analüüsida fakte, mis on seotud genotsiidi, pagendamise ja vangistamisega Nõukogude ja Saksa okupatsiooni ajal, sealhulgas koguda lugusid, mis annavad tunnistust massiküüditamiste ja vangistamiste kuritegelikust iseloomust ning tingimustest, milles küüditatuid ja vange hoiti. Andmete kogumise kõrval viib keskus läbi arvukaid teadus- ja kirjastamisprogramme.

Teine elulugusid koguv institutsioon genotsiidi ja vastupanuliikumise uurimiskeskuse kõrval on Vilniuse Ülikooli soouuringute keskus, mis asutati 1992. aastal (vt pikemalt http://www.moterys.lt/index.php?id=378). Keskuse 
juurde loodi 2001. aastal naiste mälestuste arhiiv, mis praegu sisaldab umbes 50 biograafilist intervjuud. Intervjuude tekstid on litereeritud ja kataloogitud, intervjuude sisukokkuvõtted on saadaval internetis.

Märkida tuleb ka suulise ajaloo andmete kogumist, uurimist ja avaldamist haridusalgatuste raames. Need on õpilaskonkursid ja -projektid tähtsate minevikusündmuste pärimusajaloost. Märkimisväärseimaid näiteid on kooliõpilastele suunatud kogumisvõistlus "Juudid - minu vanavanemate ja vanavanavanemate naabrid", et saada meenutusi ja esseid juutidest Leedus. Kogumisvõistlusi on aastast 2002 korraldanud ühiskondlik organisatsioon Mälu Maja (Atminties namai, vt kodulehekülge http://www.atmnamai.lt/); avaldatud on kaks raamatut õpilaste kogutud ja kirjutatud tekstidega. Leedu vabadusvõitluse ja armee teemaline õpilasvõistlus, mida organiseerib genotsiidi ja vastupanuliikumise uurimiskeskus, on toimunud 2004. aastast ja paistab silma osalejate rohkusega. Õpilased on kaasatud suulise ajaloo andmete kogumisse ja uurimisse ka Ida-Euroopa juutide kultuuri ja ajaloo uuringute keskuse (Rytu Europos žydu kultūros ir istorijos tyrimu centras, vt pikemalt http:// www.jewishstudies.lt/) juures. Programmi "Shtetlid Leedus" täitmisel kogusid Vilniuse Ülikooli üliõpilased dokumentaalseid ja suulise ajaloo allikaid juudi kogukondade kohta Leedu väikelinnades, programm on siiani töös.

\section{Lõpetuseks}

Kuigi eluloo- ja suulise ajaloo uurimine ei ole Leedu sotsiaal- ja humanitaarteadustes valdav, on selle metodoloogia rakendamine lasknud uurida teemasid ja probleeme, mida teised metoodikad ei võimalda. Nende hulgas on ka ajalooliste ja tänapäeva muutuste teemad. Leedu biograafiliste ja suulise ajaloo alaste uuringute valdkonnad ja teemad ei tundu teiste sama piirkonna riikide, eriti postsotsialistlike riikide taustal kuigi spetsiifilised: naabermaades (näiteks Lätis ja Eestis) näib eluloo- ja suulise ajaloo uurimine olevat valdavam ja rohkem institutsionaliseeritud. Ehkki eluloo- ja suulise ajaloo uurimine Leedus muutub populaarsemaks, vajab see suuremat institutsionaliseeritust (probleemidele orienteeritud konverentsid, ajakirjade temaatilised numbrid, elulooarhiivid, jne), mis aitaks kokku koguda ja kasutada ära Leedu teadusuuringute hajutatud potentsiaali. Samuti on Leedu eluloo- ja suulise ajaloo uurimisel puudus laialdasemast metodoloogilisest arutelust ja ka võrdlevast dimensioonist - suuremast osalusest võrdlevates teadusuuringutes.

Tõlkinud Ann Kuslap 


\section{Kommentaarid}

1 Teatud tegurite põhjal moodustatud valikrühm sotsioloogilises uurimuses.

${ }^{2}$ Võistluse korraldasid Laima Žilinskienè, Sigita Kraniauskienè, Rasa Ališauskienė, Eglè Laumenskaitė (Vilniuse Ülikool) koostöös J. P. Roosiga (Helsingi Ülikool).

${ }^{3}$ Vt kirjastuse tegevuse kohta URL: http://www.versme.lt.

\section{Kirjandus}

Avižienis, Jūra 2005. Mediated and unmediated access to the past: Assessing the memoir as literary genre. Journal of Baltic Studies 1 , lk 39-50.

Avižienis, Jūra 2006. Learning to curse in Russian: mimicry in Siberian exile. Kelertas, Violeta (toim.) Baltic Postcolonialism. Amsterdam/New York: Rodopi, lk 187-202.

Bertaux, Daniel 1981. Introduction. Bertaux, Daniel (toim). Biography and Society: the life history approach in the social sciences. Beverly Hills: Sage, lk 5-13.

Davoliūtè, Violeta 2005. Deportee memoirs and Lithuanian history: the double testimony of Dalia Grinkevičiute. Journal of Baltic Studies 1, lk 51-68.

Fischer-Rosenthal, Wolfram 1995. The problem with identity: biography as solution to some (post)-modernist dilemmas. Comenius 3, lk 250-265.

Kasatkina, Natalija 1994. Kasatkina, N. 1994. Rusø inteligentijos integracija á tarpukariometø Lietuvos kultûrà. Doktoriväitekiri. Vilnius: Socialinis tyrims insitutas.

Kohli, Martin 1986. Biographical research in the German language area. Dulczewski, Zygmunt (toim). A commemorative book in honor of F. Znaniecki. Poznan: Poznan University, lk 91-110.

Kraniauskienè, Sigita 2002a. Metodologiniai laiko problemos tyrimo ypatumai sociologijoje. Tiltai. Bridges. Brücken 4, lk 41-48.

Kraniauskienè, Sigita 2002b. Socializacijos modeliai lietuvis autobiografijose: lyties ir laiko aspektas. Sociologija. Mintis ir veiksmas 1, lk 66-74.

Kraniauskienè, Sigita 2003. Tapatybès konstravimas biografijose.Daktaro disertacija. Vilnius: Vilniaus universitetas (käsikirjaline doktoriväitekiri).

Kraniauskienè, Sigita 2004a. Identiteto tyrimo metmenys: kartų identiteto paieška XX a. lietuvių autobiografijose. Sociologija. Mintis ir veiksmas 1, lk 66-74.

Kraniauskienè, Sigita 2004b. Nepriklausomybès idejja lietuvių autobiografijose. Interstudia humanitatis 1, lk 24-38.

Kraniauskienè, Sigita 2005. Lyties tapatybès raiška XX a. lietuvių autobiografijose. Tiltai. Bridges. Brücken 2, lk 73-82. 
Kraniauskienè, Sigita 2007. Generations: Practical application of the concept. Balint, Balla \& Sparschuh, Vera \& Sterbling, Anton (toim). Karl Mannheim: Leben, Wirkung und Bedeutung für die Osteuropaforschung. Hamburg: Krämer, lk 195-214.

Marcinkevičienè, Dalia 2007. Prijaukintos kasdienybès 1945-1970 metai. Biografiniai Lietuvos moteru interviu. Vilnius: Vilniaus universitetas.

Marcinkevičienè, Dalia. Privatus gyvenimas sovietmečiu: rekonstrukcinès pasakojamosios istorijos galimybès. Šermukšnyte, Rūta (toim). Lietuvos istoriografija, kultūrin atmintis ir bendroji Europa. Vilnius: Vilniaus universitetas (ilmumas).

Maslauskatè, Aušra 2003. Šeimyniniai taprasmeniniai santykiai visuomenès pokyčiuose: jaunu šeimų biografinis tyrimas. Vilnius: Vilniaus universitetas (käsikirjaline doktoriväitekiri).

Maslauskatè, Aušra 2004. Meilè ir santuoka pokyčių Lietuvoje. Vilnius: Socialinių tyrimų insitutas.

Miller, Robert L. 2000. Researching life stories and family histories. London: Sage.

Potašenko 2006a = Поташенко, Григори. Староверие в Литве: вторая половина XVII - начало XIX вв. Исследования, документы и материалы. Vilnius: Aidai.

Potašenko, Grigorijus 2006b. Žodinè istorija ir jos ypatybès. (http://www.jewishstudies.lt/ index.php?921091731 - 21. oktoober 2009).

Račiūnaité, Rasa 2004. Nacionalinių vertybių ir miestietiškos sąmonès plètra: tarpukario Kaunas ir jo priemiesčiai. Lietuvos etnologija: socialinès antropologijos ir etnologijos studijos 4. Vilnius: Lietuvos istorijos instituto leidykla, lk 111-134.

Rosenthal, Gabriele 1991. German war Memories: Narrability and the Biographical and Social Functions of Remebering. Oral History 2, lk 34-41.

Rosenthal, Gabriele 1993. National identity or multicultural autobiography: theoretical concepts of biographical constitution grounded in case reconstructions. Josselson, Ruthellen \& Lieblich, Amia (toim). The narrative study of lives. Newbury Park: Sage, lk 21-29.

Silverman, David 2000. Doing qualitative research: a practical handbook. London: Sage.

Simoniukštytè, Aušra 2003. Seredžiaus romai. Girininkienė, Vida (toim). Lietuvos valsčiai: Seredžius.Vilnius: Versmè, lk 861-889.

Šutinienè, Irena 2003. Sovietinio laikotarpio atminties bruožai autobiografiniuose pasakojimuose. Šutiniené, Irena (toim). Socialinè atmintis: minejjimai ir užmarštys. Vilnius: Socialinių tyrimų institutas, lk 13-66.

Šutiniené, Irena 2004. Žydai ir holokaustas Lietuvos miestelių gyventojų kolektyvinejje atmintyje. Ragauskas, Aivas \& Senkus, Vladas \& Tamošiūnas, Tadas (toim). Lokalios bendrijos tarpdalykiniu požiūriu. Vilnius: Vilniaus pedagoginis universitetas, lk 5968.

Šutinienė, Irena 2008. Sovietinių represijų atminties reikšmės lietuvių autobiografijose. Genocidas ir rezistencija 2, lk 127-134. 
Žilinskienè, Laima 1994. Protection of Minorities in Lithuania: Qualitative Study of the Attitudes and Opinions. Survey Report. Vilnius: Lithuanian-Swedish Organization.

Žilinskienè, Laima 1998. Features of the ethnic minorities and Lithuanian in Vilnius and Vilnius District. Report of the Ministry of Education, Science, Sport and Culture of Japan Grant. Aid for International Scientific Research. Joint project number: 08044019. March, 1998.

\section{Summary}

\section{Biographical and Oral History Research in Lithuania}

\section{Irena Šutiniené}

Key words: biographical research in sociology, identity, minorities, oral history, regional studies, Socialist and post-Socialist studies

The article provides an overview of the main topics and areas of biographical and oral history research in Lithuania starting from the 1990s. The overview covers studies that analyze oral or written autobiographical narratives or deal with personal experiences of historical events. A brief summary is also given of the institutional activities in collecting biographical information and establishing archives in Lithuania. The issues and areas of biographical research in Lithuania confirm that while analyzing individual biographies of the people of Lithuania it is difficult to avoid the historical dimension, which reflects the relation of an individual with the historical factors and changes (especially, the Soviet and German occupations and the post-Socialist coup). The individual and the collective need to cope with the socio-political breaks and changing regimes have to a considerable degree determined both: the generation and collection of narratives of personal reminiscences as well as the biographical and oral history research. 